\author{
Aurelija Burinskienè \\ Vilnius Gediminas Technical University, Lithuania \\ aurelija.burinskiene@vgtu.It
}

\author{
Vita Marytè Janušauskienè \\ Vilnius Gediminas Technical University, Lithuania \\ vita-maryte.janusauskiene@vgtu.It
}

\title{
Innovations in the Practice of Production and Trade Enterprises in EU Countries
}

\author{
JEL Classification: O30, O31, O32, O33, O39
}

Keywords: innovations, enterprises, trade, production

\section{Abstract \\ Innovations in the Practice of Production and Trade Enterprises in EU Countries}

Modern theories are increasingly focusing on innovations. Scientific literature states that the implementation of innovations causes increase in sales volume: enterprises are improving the organization of production and trade methods, reducing production and trade costs, producing and selling competitive products as a result of technological progress. Technological progress also influences the development of production and trade prospects. Although the implementation of innovations is different, the main aspects are related to the novelty of product, production and service R\&D intensity and the qualification of employees. Enterprises without the capacity to innovate may invest time and resources in studies of research results but are unable to transform this knowledge into practice (Hult et al., 2004). In such sense it is important to create innovative behaviors and related outcomes on country level (Koellinger, Thurik, 2009).

Production and trade enterprises have a significant impact on the national economy, but the number of enterprises that have excellent understanding about innovations and their results is not sufficient.

Sales of the trade enterprises in the European Union amount to $66 \%$, and $74 \%$ of gross domestic product (GDP) in Lithuania. At the same time sales of the production enterprises in the European Union amount to $15.5 \%$ of GDP, and in Lithuania - $21 \%$ of GDP.

Production and trade enterprises play a significant part among business companies. In corporate structure of the European Union $9.8 \%$ of companies are production companies which employ $22.6 \%$ of EU workers, while in the structure of the European Union $28.6 \%$ of companies are trade companies and these companies employ $24.7 \%$ of EU workers. However, in the trade sector there are $90 \%$ of companies, and in the production $-84 \%$ of companies with up to nine employees (Eurostat, 2010).

Ekonomia - Wroclaw Economic Review 22/1 (2016)

(C) for this edition by CNS 
Nevertheless, the European Commission's (2013) study shows the declining contribution of production enterprises to GDP. Eurostat (2010) statistics show that small and medium-sized manufacturing companies are very slow to improve their operations and labor productivity. The EU companies are anticipated to increase by only $2.4 \%$ compared with the US companies, where growth of labor productivity is $3.5 \%$

Therefore, innovations are also important for the EU trade and production companies. To sum up the above set out material, it can be said that the application of innovations must be considered as a very complex cognitive subject.

The article consists of three parts to fully examine the implementation of innovations in production and trade enterprises.

First, literature analysis is carried out and topic related aspects are identified.

In the second part the paper presents empirical research methodology. Herein, practices of production and trade enterprises are presented, comparison of production and trade enterprises is carried out, and effects on the activeness of enterprises regarding the opportunities of innovation implementation in this area are analyzed.

In the third part the article presents empirical research results, conclusions and recommendations. Literature analysis reveals that the greatest role innovation plays in international companies, however the number of such enterprises is very small in the EU. The results also show that production and trade companies from Luxembourg have higher competitiveness than the enterprises from other countries. Overall the paper glances into whether, to what extent, how companies innovate, and how this differs between production and trade service industries.

\section{Introduction}

Nowadays "innovation" refers to a new technology, product or service, its promotion into the wider customer market, the result of growing awareness of potential clients and spread in other markets. In terms of innovation, it is difficult to draw a distinction between trading and manufacturing companies at enterprise level.

New products are typically highly tangible and visible. This is often different with new services. Only those service innovations are visible where delivery of the product is involved, while in other cases a much more intangible characteristic of new service (idea or solution to a problem) is related (Hertog, 2000). Although innovation concept may already exist in other markets, the novelty is in its application in particular market. Usually in innovation research there are thorny problems concerning when a product, function or concept is really new. Opinions can vary depending on whether and when it is considered new in each case: new for the client; for the regional, national or global market or it involves new scientific knowledge (Lee et al., 2012).

M.E. Porter (1999) defines innovation as a key competitive factor for enterprises in national and international markets.

There are several perspectives of enterprise behavior; it may simply focus on how to beat the competitors, or build and improve competitive advantage through activity oriented at innovations.

The global spread of technology is becoming increasingly dependent on multinational corporations, business associations and international organizations. 
Internationally operating organizations develop and promote the implementation of technologies with certain characteristics. They usually affect the use of technologies in the field of product realization globally.

In today's economy, more attention is paid to the technological progress. Over the last decade, innovation capacity has doubled, but their presence in the market has become much shorter than in the past. As a result, innovation can take many forms: the emergence of entirely new technology or a modification of existing technology into a more advanced one.

The prevailing opinion is that an economically strong entity which still uses old technology, in competition usually loses to an enterprise which applies advanced technology (Jakštas, 2001), since relatively higher operational productivity and efficiency can be achieved with the new technique. In particular, if the effect is seen in public; such innovations are capable of achieving the highest results.

In the economy of globalization and application of knowledge, due to the European Union development and enlargement of EU production and trade companies, new opportunities arise for innovation performance, increase in competitiveness throughout the world, and in turn increase in the volume of sales.

The growth of economic activity is directly related to innovation. Scientist E. Denison, who examined the US economy for the 1929-1979 period has found that innovation is influenced by economic growth. He estimates that if national income during the considered period increased an average of $2.98 \%$ per year, as a consequence innovations would influence the country's national income growth by $0.73 \%$ (Jakutis et al., 2005).

American economist R. Solow also found that in 1909-1949 United States more than $80 \%$ gross domestic product (GDP) growth was due to technological progress (Balkytè, Valentinavičius, 2006).

The neoclassical growth model (Solow-Swan), which states the level of technological progress, also mentions volumes of continuous investment into technology. Increasing investments in technology begin the upturn - the transitional period, which is special due to the accumulation of physical capital and uptake of new technologies (Marelli, Signorelli, 2010). Total production (in the broad sense) and the capacity load increases during this period. Later the equilibrium is reached, which is characterized by the maximum production capacity load or lack of it.

At the same time it should be noted that technological progress, which manifests itself through application of new technologies' phenomena, new technologies' factors, takes place in modern economy. As a result, innovation time in the market decreases, new challenges arise, important for both application of innovations and business administration. New challenges for the development of innovation application in the modern economy especially affect the uptake of innovations in the field. This encourages the assessment of the active uptake of innovation businesses opportunities. 
The acceptance of innovations is also very important for the management, scientific and practical work areas.

Innovation is used for both small improvement and substantial redevelopment. These improvements and adjustments could lead to fundamental changes and progress (Melnikas, 2002). Change processes are taking place purposefully. These processes are treated as very complex and multifaceted. They have to be provided to ensure a higher level of production and user service (Melnikas et al., 2008). Organizational changes could go into two directions: focus on flexibility, spontaneity and individuality or higher control, stability and order (Deshpande et al., 1993). Many authors believe that enterprises are operating in more complex environments than ever before. In complex enterprises it is important to consider the growing environmental constraints, increasing sophistication of technology and strategic issues of organizational behavior. A key component for the success of enterprises is the extent of their capacity to engage in innovation, i.e. introduction of new processes, products or ideas in the organization (Hurley et al., 2005). This capacity to innovate is among the most important factors that have impact on business performance (Olson et al., 2005).

It is interesting that during the last decade innovations have doubled in quantity and the market time of innovations is now much shorter than before. The innovation implementation speed has become important.

In an environment where market preferences are constantly changing, consumers are continuously seeking new products, and new enterprises are entering the market on a regular basis, in this stage it is important for enterprises to engage in innovative activities in order to achieve superior performance (Woodside, 2005). The measure of such fast market entry can only be reached together with business partners. Producers, wholesalers and retailers are highly connected and maintain coordination among each other when pushing innovation to the market, while in other cases regular contacts with business partners are not maintained at such level (Fang, 2008).

Innovation actions performed by enterprises involve a broad spectrum of activities such as developing new technologies, products and services, supportive leadership, as well as interaction with information and communication technologies (Tajeddini, 2010).

The analysis of topics associated with the implementation of innovations is also considered a viable research area. The aim of this research is to find out the circumstances which determine the implementation of innovations and factors influencing the activity of enterprises in this area. This particular research is determined by the need to identify and deal with the following essential problems:

- lack of a systematic approach to innovation and activation issues (when it comes to activeness of enterprises and sector-specifics);

- focus on business changes which are affected by the implementation of innovations.

Research methods: statistical, comparative, empirical and systematic analysis. 


\section{Theoretical framework of the research}

The analysis of the economic science literature (scientific literature published by famous world publishers such as Oxford University Press, Cambridge University Press, Harvard University Press, Springer, M. E. Sharpe, Routledge, etc.) shows that the authors who published textbooks on the topic of trade have given little attention to the questions of innovation implementation analysis (only $0.2 \%$ of the authors). Also the authors who published textbooks on the topic of innovations have given little attention to the particularities of the trade sector (only $1.3 \%$ of the authors).

A similar situation is observed in all relevant literature dedicated to the production topic. Amongst the authors who published books on production topic, only $0.4 \%$ has given attention to the implementation of innovations. And the authors who published books on innovation topic have given little attention to the particularities of production sector - only $2.75 \%$.

The results show that there is a lack of attention to the acceptance of innovations at manufacturing and trade companies in the literature.

The greatest contributions in this area are delivered by international companies. Although in each case the uptake of innovations is unique, scientific literature examines cluster and internal absorption systems of international companies, which are inherent for the uptake of innovations (Maceika, 2003).

Cluster systems can create vertical or horizontal strategic alliances in the enterprise. Competition and business cooperation problems must be solved when establishing the horizontal strategic alliance. Companies are required to form a harmonious strategy to strengthen the strategic alliance, positions of partners, and to ensure the advantage of strategic alliance (Knašas, 2002).

Large multinational corporations are companies with the most advanced technology uptake. Among the Swedish and German trade companies that apply innovations, the highest proportion belongs to multinational companies (Eurostat, 2010).

Technology uptake is important in shaping the international competitiveness of enterprises (Knašas, 2002). International companies can accelerate the uptake of technologies since they have enormous intellectual and financial resources. Discontinuous innovation activity may result in both: customer-oriented behaviors or pure R\&D driven innovations in some cases (Cohen, Levinthal, 1998).

The uptake of technology strategy in international enterprises is shaped by the decision of parent company to distribute the technology among its branches. Such technology absorption system can be called internal absorption system of the international company. The parent company may conclude a contract and use the technology throughout the company, but cannot transfer the license to branch offices without the agreement of technology distributor. The parent company and distributor of technology want to facilitate a technology absorption process, but frequently have to adapt the technology for the needs of branches operating in 
different markets. International corporate internal absorption system operates communication networks in order to exchange information between branches and corporate headquarters. International companies use intranet, where they gather all technological learning experience.

When examining the uptake of innovations there are several innovation uptake strategies applied in companies, namely:

- steering the development of the strategy; strategy which requires a leadership role in harnessing innovation sector;

- repeatable development strategy; in this case the company does not seek to create new products or processes, but instead tries to keep up with competitors, improve existing products, generally in order to make them cheaper;

- adaptive development strategy; in this case, the company itself does not create new products, and instead it purchases production documentation of the already created product.

Scientific publications identified a number of technologies related to the introduction of models, but only a few of them are designed to implement technologies in enterprises. The first model is a technology deployment model (Technology Acceptance Model TAM2) (Davis, 1989), the second model is an explanation of the factors influencing companies' decisions to apply technologies (Technology-Organization-Environment Model TOE) (Rogers, 1962). These models are mentioned in the context of enterprise solutions for the use of technologies for collecting and transmitting information about the technology to business partners and clarifying other issues.

Technology Acceptance Model. The model is intended for new information technologies (applications and information systems) to be set up in enterprises. The pioneer of this model is F. Davis (1989). The model explains striving to use technology and comprehend its benefits.

With the introduction of innovations, related questions have to be regarded as a promising area for research. According to F. Davis (1989), perceived benefits is a realization of the staff that the use of technology will improve their performance; ease of use means use of particular technology without a lot of effort.

According to this hypothesis, the easier use, the better employee reaction to the new technology and greater intention to implement it. This new model became known as TAM2.

Technology-Organization-Environment Model, pioneers - L.G. Tornatzky, M. Fleisher. According to the authors, corporate decisions to apply technology are influenced by technological, organizational and environmental factors (Tornatzky, Fleisher, 1990):

- technological factors - internal and external technological solutions required for the development of a company. Technological solutions for the enterprise include actions related to the technological solutions for use within the company, in order to introduce innovation and expand the business processes and 
technology solutions, while external solutions include adoption and use of technology by external market representatives;

- organizational factors - company's resources and its characteristics: size, structure and complexity of the managerial aspects of the quality of human resources;

- environmental factors - size of the market, competitors, suppliers, macroeconomic factors and the legal regulation of business processes.

It can be argued that all three factors reveal not only the opportunities but also the limitations that are particularly relevant when companies seek modern technologies.

O.A. Hart, M.N. Barinedum and J.I. Benjamin (2010) provide a modified technology-organization-environment model, which associates dimensions of technologies model (TAM2) and technology-organization-environment model (TOE), affecting intelligent decision-making and application.

O.A. Hart, M.N. Barinedum and J.I. Benjamin proposed that the model be applied to small and medium-sized businesses in those cases when business is focused on the development of innovative technologies. It reveals the attitude towards the use of technology and evaluates the benefits of technology (results). Small businesses in a big country can be a bit more relaxed because of a huge domestic market. However, SME of a small country need to cover R\&D expenses, which is impossible by focusing only on the domestic market, since they have to be more international market oriented (Mets, 2012).

The European Commission has carried out a few studies and found a correlation between corporate funds allocated to research and development and introduction of new products. The conclusion is that research and experimental activities have a direct impact on the introduction of new product innovations. Practice shows that subsectors with companies carrying out intensive research and experimental work have introduced more product innovations, as the activities directly correlated with the obtained results (European Commission, 2011). Innovation has a positive impact on the company - the most innovative subsectors of wholesale and retail trade sector experience higher growth. Such trading sector companies increase the business volume, labor productivity, as well as extend the number of employees. Therefore, it is noted that innovation has a positive impact on these sectors - companies experiencing higher growth in the trade sector (European Commission, 2011). At the same time it should be noted that on average companies allocate $1.5 \%$ of their income to innovations. And companies that already have implemented innovations increase their turnover by $18 \%$ (Eurostat, 2006).

Upon completion of the literature analysis it should be noted that companies' practices should be understood and analyzed when considering the application of innovations. Meanwhile, scientific articles pay very little attention to such studies. Therefore this article aims to reveal the company's ability to innovate in the current challenging conditions, compare entities operating in different countries, 
assess whether the company, taking into account new circumstances, is able to adequately respond and adapt.

In summary it can be said that the greatest role in innovation implementation is played by major international companies. Their activities are exceptionally significant in implementation of innovations. However, there are not many large companies among production and trade companies in the European Union. Therefore, there is a lack of attention to innovations in small production and trade companies which employ up to nine people. In order to increase competitiveness, these companies should intensify cooperation with large enterprises and, in turn, apply the uptake of innovation strategies.

Literature analysis showed the importance of innovations. The authors, who publish works on the theme of innovations, mainly follow three ideas: (1) stimulation of the implementation of innovations, (2) implementation of technological innovations in private companies, and (3) contributions of business partners to stimulate the implementation of innovations.

There are differences in the classification of innovations: the level of novelty, the scope of implementation, the level of impact. Any change which achieves higher performance results is called business innovation. Success indicators are the innovations' drivers, such as business collaboration, competitive environment, knowledge about the information use, sales opportunities, etc.

Based on the study's theoretical results, in order to compare the production and trade enterprises, the system will be supplemented by the criteria that reflect the implementation of technological innovation, business collaboration, product innovation and criterion determining the intensity of competition.

\section{Research methodology}

The study is based on the methodology which covers: (1) systematic approach; (2) concept used for the activation of innovations; (3) comparison of enterprises.

Systematic approach is the methodological basis of systematic analysis. The essence of the systematic approach is research of the complex object as aunified system.

The concept of innovation activation rests on mathematical methods used to determine the regularities of changes and impacts.

The company comparison is intended to determine the peculiarities of production and trade companies in different European Union countries.

Formulated tasks for empirical research:

- to analyze the practice of implementation of innovations by production and trade enterprises and depict the situation in the European Union and Lithuania;

- to deliver the comparative analysis of production and trade enterprises;

- to revise business changes which are affected by the implementation of innovations. 
The authors identified key research areas in order to carry out the research goals:

- study used to disclose the implementation of innovations by production and trade enterprises. During the examination closest attention is paid to the following issues: innovation diversity and changes in companies which are affected by the implementation of innovations. The study is based on empirical, statistical and comparative analysis;

- study dedicated to compare the production and trade enterprises located in different countries. This study allows for evaluating the ability of production and trade enterprises to adapt to changing environmental conditions and revise the opportunities to implement different types of innovations. The study is based on multi-criteria evaluation method;

- study used to highlight the impact on activeness of production and trade enterprises to implement innovations. The effect related to the expansion of information technology, research and development activity in certain countries is assessed in this study.

The term "technological innovations" is used in the first study. It means the implementation of a product, process, ongoing or abandoned innovation in the active enterprises. Innovations of technological products and processes (TPP) must be distinguished from organizational innovations and other changes in products and processes. Technological process innovation is the adoption of technologically new or significantly improved production methods, including the methods of product delivery. These methods may involve changes in equipment, production organization or a combination of these changes when using new knowledge. Methods may be applied with intention to produce or deliver technologically new or improved products, which cannot be produced or delivered using conventional methods, or in order to reach production or delivery efficiency of existing products (Eurostat, 2010).

In the second study, where the comparison of production and trade enterprises is provided, multi-criteria evaluation method is used.

The study was carried out in 14 European Union countries. All the necessary data has been published by the following countries: Austria, Bulgaria, Czech Republic, Denmark, Estonia, Italy, Latvia, Lithuania, Luxembourg, Portugal, Romania, Slovenia, Slovakia, and Sweden.

The assessment of the Eurostat survey sample showed that it is sufficient. In order to ensure $95 \%$ reliability of the survey and $4 \%$ of permitted inaccuracy, at least $1.20 \%$ of trading companies and not less than $1.22 \%$ of the production companies must be surveyed. Meanwhile 3.91\% of production companies and 2.14\% of trade companies were questioned by the Eurostat survey.

The comparison of production and trade enterprises was based on E. K. Zavadskas, L. Simanauskas, and A. Kaklauskas proposed multicriterial complex proportional evaluation methodology (Zavadskas et al., 1999). The mentioned methodology has allowed to normalize different types of criteria (criteria which 
characterize the activeness of production and trade enterprises and their ability to implement innovations), and that led to the final decision.

In the first task a decision matrix is formed with as many columns as there are criteria and as many rows as there are comparable items. It is very important to identify the criteria (indicators) weights (relevance) for the application of multi-criteria methods (Podvezko, 2005). After that the decision-making matrix is normalized - transformed into a matrix where the numerical value of the criteria has no units of measurement. Further the normalized decision making matrix is weighed: each criterion is multiplied by the corresponding relevance of the criterion, where the total amount of the criteria's relevance is equal to one (Turskis et al., 2009).

Each decision-maker has his own preferences, but quantitative evaluation allows for defining their impact in the final decision.

Managers have been dealing with multi-criteria issues for a long time. Numerous methods have been developed for analyzing such problems. One of the multi-criteria methods is a method of COmplex PRoportional ASsessment of alternatives (COPRAS). During the application of method direct and proportional dependencies are assumed, and the alternatives, values and weights of criteria are adequately described (Turskis et al., 2009). The COPRAS method is used widely among Lithuanian scientists (for example by Andriuškevičius, 2005; Bivainis, Drejeris, 2009; Ginevičius, Podvezko, 2009; Ginevičius, 2008; Ginevičius, Podvezko, 2007; Kaklauskas et al., 2007; Kildienè et al., 2011; Malinauskas, Kalibatas, 2005, and others).

Complex evaluation is used in the study and it allows to:

- use the generalized indicator which characterizes companies;

- evaluate different and even mutually contradictory criteria;

- take into account the importance of different criteria to the evaluation results.

Twelve criteria were used to compare the production and trade enterprises. These criteria characterize companies which:

a) implement product innovations,

b) implement process innovations,

c) trade in local/regional market,

d) trade in national market,

e) cooperate with other enterprises,

f) are faced with a lack of partners for business development,

g) are faced with a fierce competition,

h) are faced with the effective use of information technology problem,

i) develop variety of products and services,

j) aim to increase sales,

k) aim to enter international markets,

1) aim to find business partners. 
The criteria list is divided into three groups. The first group consists of criteria defining the activeness of enterprises $(\mathrm{a}-\mathrm{e})$, the second - parameters describing the capabilities of enterprises $(\mathrm{f}-\mathrm{h})$, the third - criteria overviewing the strategic objectives of enterprises (i-l).

Selected criteria are very important when analyzing the activeness of production and trade enterprises, taking into account the ability to impact the innovation activation process and opportunities for development of such skills by these enterprises.

Selected criteria allow for specifying phenomena relevant to the public and business sectors, assessing effects caused by these changes. Such effects can be attributed to the implementation of information technology, which is treated as technological innovation; also the activeness of production and trade enterprises when implementing innovations and selling goods.

The criteria system was established by taking into account all the criteria describing researched enterprises. Quantitative criteria weights were determined by experts. The criteria from the first category received the highest score, while the criteria from the second group received less attention from experts than the criteria from the third group. The compatibility of expert opinions was evaluated using concordance coefficient. In this case it is equal to 0.75 (the significance of concordance coefficient is 107.25 and is higher than the critical value, which is equal to 19.67 , which shows that expert assessments are compatible).

It is important to determine the weight of each criterion when applying the multiple criteria approach. Further the criteria weights are put in a matrix, and the formed matrix is normalized.

Criteria numerical values $b$ have no units of measurement in the formed matrix, e.g. each criterion value is multiplied by the corresponding weight criterion $R$ when the total sum of the criteria is equal to 1 , calculated according to the formula 1 and 2:

$\sum_{i=1}^{12} R_{1}=1$

$b_{i j}=\frac{d_{i j} R_{i}}{\sum_{j=1}^{n} d_{i j}}, i=\overline{1,12} ; j=\overline{1, u}$,

where $x$ - specific criteria, $R$ - criterion weight, $d$ - value of the criterion, $u-$ number of countries, $i$ - number of criteria, $j$ - country, $S$ - sum of criteria values, directions: Min - minimizing value is better, Max - maximizing value is better. 
Table 1. Constructed matrix

\begin{tabular}{|c|c|c|c|c|c|c|c|c|}
\hline \multirow{2}{*}{\multicolumn{3}{|c|}{ Criteria }} & $\mathrm{Co}$ & ared $c$ & rpris & $u \mathrm{cc}$ & ries & \multirow{3}{*}{$\begin{array}{c}\text { Sum of criteria } \\
\text { values }\end{array}$} \\
\hline & & & 1 & 2 & 3 & $\ldots$ & $u$ & \\
\hline Title & Direction & $\begin{array}{c}\text { Weight } \\
\text { of criterion }\end{array}$ & \multicolumn{5}{|c|}{ Value of criteria for specific enterprises } & \\
\hline$x_{1}$ & $\operatorname{Max}$ & $R_{1}$ & $d_{11}$ & $d_{12}$ & $d_{13}$ & $\ldots$ & $d_{1 u}$ & $S_{1}=\sum_{j=1}^{n} d_{1 j}$ \\
\hline$x_{2}$ & Max & $R_{2}$ & $d_{21}$ & $d_{22}$ & $d_{23}$ & $\ldots$ & $d_{2 u}$ & $S_{2}=\sum_{j=1}^{n} d_{2 j}$ \\
\hline$x_{3}$ & $\operatorname{Max}$ & $R_{3}$ & $d_{31}$ & $d_{32}$ & $d_{33}$ & $\ldots$ & $d_{3 u}$ & $S_{3}=\sum_{j=1}^{n} d_{3 j}$ \\
\hline$x_{4}$ & $\operatorname{Max}$ & $R_{4}$ & $d_{41}$ & $d_{42}$ & $d_{43}$ & $\cdots$ & $d_{4 u}$ & $S_{4}=\sum_{j=1}^{n} d_{4 j}$ \\
\hline$\cdots$ & $\cdots$ & $\cdots$ & $\cdots$ & $\cdots$ & $\cdots$ & $\cdots$ & $\cdots$ & $\ldots$ \\
\hline$x_{12}$ & $\operatorname{Max}$ & $R_{12}$ & $d_{121}$ & $d_{122}$ & $d_{123}$ & $\ldots$ & $d_{12 u}$ & $S_{12}=\sum_{j=1}^{n} d_{12 j}$ \\
\hline
\end{tabular}

Source: constructed by authors.

The amount of normalized values $b_{i j}$ of specific criterion is equal to weight $R_{i}$ of criterion $x_{i}$.

Further the amounts of normalized values of minimizing $S_{-j}$ and $S_{+j}$ maximizing criteria for enterprises in different countries (according to the formula 3 ) are calculated:

$S_{+j}=\sum_{i=1}^{12} b_{+i j}$

$S_{-j}=\sum_{i=1}^{12} b_{-i j}, i=\overline{1,12} ; j=\overline{1, u}$

The total amount of corporate minimizing criteria for all examined countries is calculated by formula 4 :

$S_{+}=\sum_{j=1}^{u} S_{+j}=\sum_{i=1}^{12} \sum_{j=1}^{u} b_{+i j} \quad S_{-}=1-S$

Compared priority of the enterprises in different countries $Q_{j}$ is determined by amounts of normalized values of characterizing minimizing and maximizing criteria, taking into account the $S_{-\min }$ value of the country with the lowest minimizing significance.

$$
Q_{j}=S_{+j}+\frac{S_{-m i n} \sum_{j=1}^{u} S_{-j}}{S_{-j} \sum_{j=1}^{u} \frac{S_{-m i n}}{S_{-j}}}, j=\overline{1, u}
$$


The higher $Q_{j}$, the greater advantage of companies in that country. If $Q_{1}>Q_{2}>Q_{3}$, then companies from that country gain a comparative advantage over other countries.

The third study is based on a multiple correlation and regression analysis. During the research the dependence between the implementation of innovations by production and trade enterprises and the expansion of information technology, research and development activities in specific countries have been identified. Prediction capability is the main aim of the research. The study focuses on the use of a predictor variable and the criterion variable. A variable which is used to predict the value of the other variable is known as the predictor variable, and the variable whose value is being predicted is known as the criterion variable. Therefore, correlation could help to identify tendencies between variables. Correlation coefficient $r$ is used in order to determine the relation between two variables. Range of the correlation coefficient is between -1 to +1 . Value of the correlation coefficient shows the nature of the relationship between multiple variables, its intensity and direction. Ideally, when there is no correlation between these variables, the value $r$ should be 0 and for a perfect correlation, the value $r$ should be 1 .

These are very rare scenarios and ideally, if the value of $r$ is above 0.70 , the relationship is considered to be "almost always significant". Direction signifies the manner in which the two variables move in respect to each other.

Through the magic of mathematics we determine the outcome of the correlation. Only active enterprises, which sold products in local or regional markets during the analyzed period, are used in calculations. All these enterprises were active during the whole or some part of the reference period.

Expansion of information technology, research and development activities are considered as expenditures of enterprises or other bodies, and are treated as investments and calculated as a percentage of gross domestic product in the study.

The study was carried out in 23 European Union countries. All the data necessary for the research was published by the following countries: Austria, Belgium, Bulgaria, the Czech Republic, Denmark, Estonia, Finland, France, Germany, Greece, Hungary, Italy, Latvia, Lithuania, the Netherlands, Poland, Portugal, Romania, Slovakia, Slovenia, Spain, Sweden, and the United Kingdom.

During this study the author constructed multiple regression equation, which is adequate to the real situation. Equation is used for the evaluation of the impact of investments on information technology, research and development activities on the activeness of production and trade enterprises.

The term "research and development activity", which is used in the study, is defined as a systematic knowledge-oriented work, including human, culture and society, and use of this knowledge for practical purposes. There are three areas of research and development activities: basic research, applied research and technology development. Basic research is an experimental and (or) theoretical work done on the substance of phenomena and observable facts without any particular application or use. Applied research - experimental and (or) theoretical 
work for particular application objectives or tasks. Development (experimental development, applied research activity) - systematic work based on accumulated research and practical experience knowledge, with the aim to create new materials, products and devices, install new processes, systems and services, or to substantially improve already existing ones.

The main methodological provision used in the research: activeness of enterprises is perceived as the number of enterprises which implemented different innovations.

The research is based on the data from the Eurostat (2010) study. The number of production and trade enterprises which implemented innovations in European Union countries is used during the survey.

Scientific novelty is shown by empirical results which validate the theoretical assumptions that it is necessary to encourage enterprises to innovate and that the expansion of information technology, research and development activities encourages the production and trade enterprises to implement them.

The relevance of empirical research - integrated assessment of the implementation of innovations, which is used to promote the expansion of production and trade, is particularly relevant in a changing environment.

The obtained results can be applied for finding new production and trade means to stimulate their development.

\section{Innovations in the practice of production and trade enterprises}

Among European Union production sectors, innovations are implemented most actively by the German production sector. Generally, $10 \%$ of production enterprises have introduced product innovations, $9 \%$ - process of innovations.

Among European Union trade sectors, innovations are implemented most actively by the Swedish trade sector. In total $7.4 \%$ of trade enterprises have implemented product innovations, $8.8 \%$ - process innovations, 9.3\% - a combination of product and process innovations. Among them the most active are wholesale trade enterprises $(33 \%$ of wholesale trade enterprises are engaged in innovation activities (36\% in Finland, 52.6\% in Sweden), 7\% have implemented product innovations, $13 \%$ - process innovations, $10 \%$ - a combination of product and process innovations). Among trade enterprises the least active are retailers (20\% of retail companies are engaged in innovation-related activities). For retailers the most relevant are process innovations (13\% of retailers have implemented them). Enterprises which implemented innovations have increased their turnover by $18 \%$.

Among Lithuanian trade enterprises the most active are wholesale enterprises (7.2\% have implemented product innovations, $10.9 \%$ - process innovations, $6.5 \%$ - a combination of product and process innovations). Among trade en- 
terprises the least active are retailers. For retailers the most relevant are process innovations (7.2\% of retailers have implemented them).

Some $20.3 \%$ of Lithuanian trade enterprises have implemented marketing innovations and 6.3\% - organizational innovations (but due to the limitation of research these innovations are not included in the study provided below).

The average number of production enterprises which apply technological innovations is $8.7 \%$, and of trade enterprises - $4.9 \%$. Sweden, Germany and France enterprises among production enterprises, and Belgium, Sweden and Denmark enterprises among trade enterprises are the most active in the implementation of technological innovations. The results of the Eurostat survey show that enterprises which have higher turnover are more innovation-oriented.

Information technology, as technological innovation, is used in Lithuania for various purposes: more than $34.2 \%$ of trade companies send electronic orders to trading partners; $16.7 \%$ of trade enterprises receive automatically processed invoices from their business partners; $22.2 \%$ of trade companies receive automatically processed transport documents from partners; $26.1 \%$ of enterprises engaged in the trade share information about the progress of the transportation of goods with business partners; $29.1 \%$ of them share forecasts, plans, information on the availability of raw materials stocks with suppliers; $13.4 \%$ of those enterprises link order management system with suppliers (Department of Statistics, 2010).

According to the Eurostat (2010) data, innovations help companies to increase capacity, improve production and service flexibility, reduce the demand of labor per production unit, penetrate new markets and increase market share, improve customer service, increase efficiency of use of raw materials and energy, reduce product costs. For example, $27.4 \%$ of Luxembourg trade companies, which implemented innovations, increased capacity; $7.5 \%$ - reduced demand for labor per production unit; $34.5 \%$ - started to penetrate new markets and increased market share; $49.3 \%$ - improved customer service; $10.6 \%$ — reduced product costs. $14.5 \%$ of Swedish trade enterprises, which implemented innovations, increased capacity; $9.96 \%$ decreased demand for labor per production unit; $17.9 \%$ - started to penetrate new markets and increased market share. $34.4 \%$ of Luxembourg production enterprises, which implemented innovations, increased capacity; $25.0 \%$ — reduced demand for labor per production unit; $30.8 \%$ — started to penetrate new markets and increased market share; $28.1 \%$ — improved customer service; $17.3 \%$ - reduced product costs. $26.65 \%$ of Swedish production companies, which implemented innovations, increased capacity, $23.2 \%$ - reduced demand for labor per production unit; $17.8 \%$ — started to penetrate new markets and increased market share (Eurostat, 2010). As we can see, companies expand their capabilities with the implementation of innovations by seeking to ensure the transfer of goods over long distances.

When talking about business changes which are affected by the implementation of innovations, it is evident that innovations help companies to improve 
capacity, increase production or service flexibility, reduce the demand for labor per production unit, penetrate new markets and increase market share, improve customer service, increase efficiency of use of raw materials and energy, reduce product costs. The results of the study validate the importance of information technology (as technological innovation) and importance of innovations when trying to penetrate new markets.

\section{The comparison of production and trade enterprises located in different countries}

For the comparison of production and trade enterprises located in different countries the Eurostat data was used.

The results of comparison of production enterprises showed that the adaptability of Luxembourg and Slovenia production enterprises to changing environmental conditions is the best. Among Luxembourg and Slovenia production enterprises: $28 \%$ have implemented innovations $(33 \%$ - product innovations and $22 \%$ - process innovations); $31 \%$ seek to implement them; $47 \%$ of production companies seek to increase sales; more than half of production companies aim to sell products in international markets.

It was also found that among all the concerned European Union production companies: $34 \%$ have implemented innovations; $25 \%$ pursue to implement them; $33 \%$ of production companies seek to increase sales; half of production companies aim to sell products in international markets; $21 \%$ of production firms are faced with problem of effective implementation of information technology as technological innovation.

The results of comparison of trade enterprises showed that the adaptability of Luxembourg trade enterprises to changing environmental conditions is the best. Between Luxembourg trade companies $66 \%$ of enterprises have implemented innovations ( $85 \%$ - product innovations, and $47 \%$ - process innovations); $31 \%$ of them seek to implement innovations (i.e. to develop not only products but also the diversity of services); $43 \%$ of trade companies seek to increase sales $(54 \%$ of them aim to increase sales in international markets).

It was also found that among EU trade companies, 30\% of companies have implemented innovations $(48.1 \%$ — product innovations, and $10.5 \%$ — process innovations); $20 \%$ of them seek to implement innovations (i.e. to develop not only the goods but also a variety of services); $22 \%$ of trade enterprises seek to increase sales (only one third of them aim to increase sales in international markets).

It is evident that the abilities of Lithuanian production and trade enterprises compared with other countries are quite similar. It was found that Lithuanian production and trade enterprises are faced with the lack of business partners and are actively cooperating with other enterprises. 
It was found that Portuguese trade companies and Italian production companies have the lowest capacity to adapt to changing environmental conditions.

Research results showed that only a fifth of the European Union's production and one third of trade enterprises have implemented innovations. A quarter of production enterprises and a fifth of trade companies seek to implement innovations. Among innovations the most popular are product innovations.

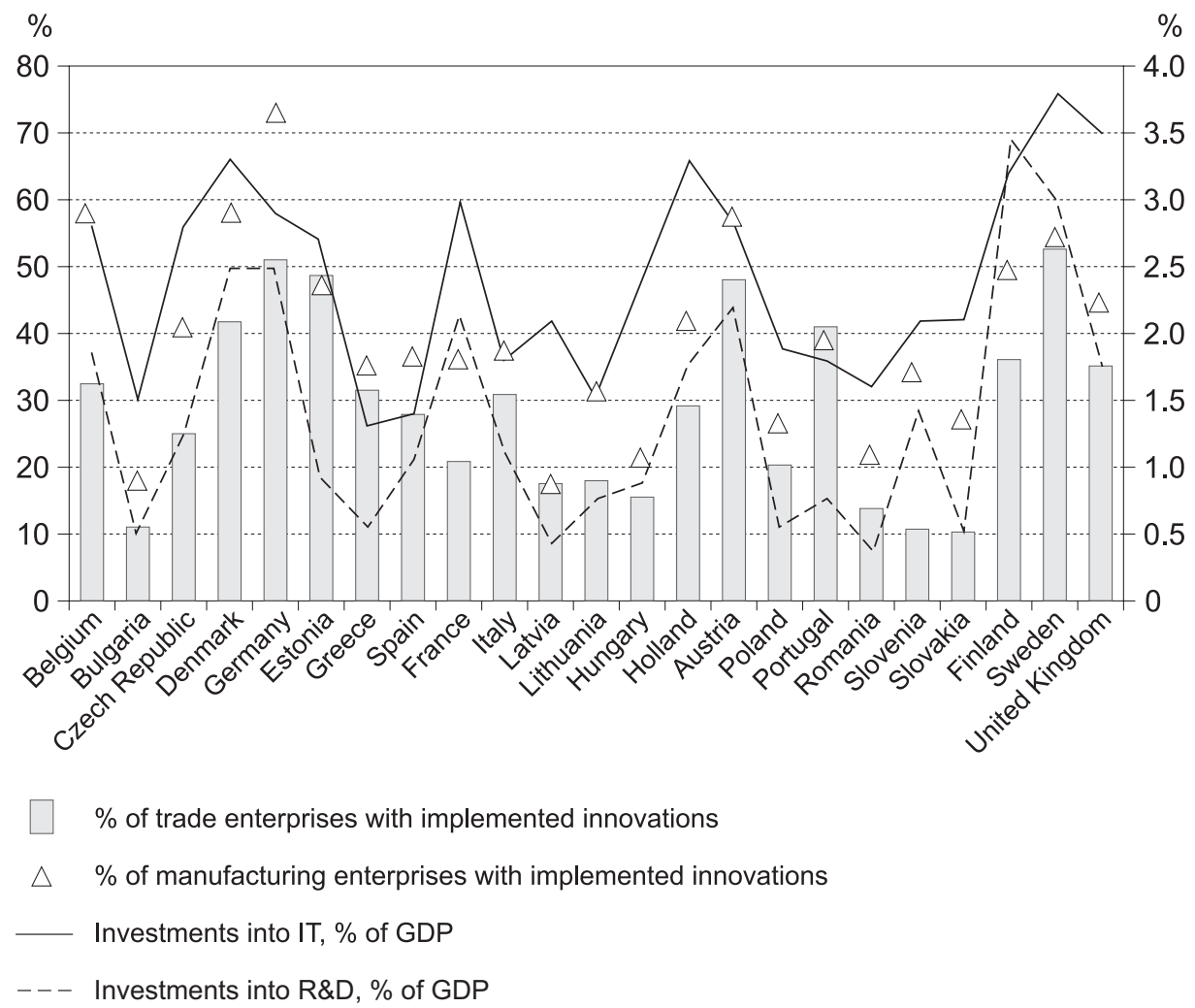

Figure 1. Production and trade with implemented innovations and expansion of the information technologies, research and development activities

Source: constructed by authors using the Eurostat data.

It was also found that the activeness of Luxembourg production and trade enterprises is exceptionally significant and important in assessing innovation priorities. $44 \%$ of production companies and $85 \%$ of trade enterprises have implemented innovations. Most of Luxembourg trade and production companies are faced with fierce competition, lack of effective application of information technology and lack of business partners. These enterprises are characterized as seeking growth of sales and increasing the variety of products and services oriented at sales. 
It was found that trade enterprises have better capabilities to implement innovations. Also these sector-specific details were revealed - production and trade companies need to purposefully implement such innovations, which ensure the development of trade, or sell new and improved existing products that would be successful in new markets, introduce process innovations in order to create the capacity necessary for the development of trade and increase the variety of services.

In this space it becomes clear that companies belonging to member states with smaller markets (Luxembourg, Slovenia, Lithuania) are more active through innovation and adaptation to changing environmental conditions than companies in countries with larger markets (the Czech Republic, Italy, Portugal, Romania).

It was also found that when seeking to promote innovations, which ensure the development of sales, more attention should be paid to their purposeful implementation in production and trade enterprises.

The study was used to highlight the impact on activeness of production and trade enterprises in innovation implementation.

When analyzing different situations and opportunities of sales development, it is necessary to evaluate the activeness of production and trade enterprises in the implementation of innovations and examine the effect options for company activeness.

During the course of research the author has found that a stochastic relationship exists between the expansion of information technology, research and development activities in specific countries and the activeness of enterprises in innovation implementation. Research results are presented in Table 2.

Table 2. Correlation results

\begin{tabular}{l|rl}
\hline Corelation coefficient & 0.78 & 0.63 \\
\hline T statistic & 3.87 & 3.62 \\
\hline T table & 2.08 & \\
\hline Coeficients & & \\
\hline $\mathrm{a}_{0}$ & 0.21 & 0.12 \\
\hline $\mathrm{a}_{1}$ & 0.62 & 2.62 \\
\hline $\mathrm{a}_{2}$ & 12.29 & 7.69 \\
\hline The adequacy of equation & & \\
\hline F statistic & 15.71 & 6.42 \\
\hline F table & 4.32 & \\
\hline
\end{tabular}

Source: constructed by authors.

In examined cases the relationship is medium or stronger. Correlation coefficients are significant, and the regression equation is adequate to the real situation.

In particular, the number of manufacturing and trading companies which apply innovations is associated with investments in IT and research and develop- 
ment. There are a number of interdependencies between investment volumes and the number of companies which apply innovations. This dependence can be expressed in such regression equation for manufacturing companies:

$y=0.21+0.62 x_{1}+12.29 x_{2}$,

where $y$ - the number of manufacturing companies which apply innovations; $x_{1}$ - investments in IT (\% of GDP), $x_{2}$ - investments in research, and development ( $\%$ of GDP) and for trading companies:

$z=0.21+0.62 x_{1}+12.29 x_{2}$

where $z$ - the number of trading companies which apply innovations; $x_{1}-$ investments in IT (\% of GDP), $x_{2}$ - investments in research and development ( $\%$ of GDP).

The authors found that the linear regression equation adequately describes the relationship between expansion of information technology, research and development activities in certain countries, and activeness of enterprises in the same examined countries. For example, with respect to the wholesale trade enterprises, the multiple correlation coefficient is equal to 0.975 (when the regression variance -0.09 , and the residual variance -0.004 ), the coefficient of determination - 0.95. The large value of the coefficient of determination shows that the main factors influencing the activeness of companies oriented at the implementation of innovations are included in the linear regression equation. The authors also found that constructed equation explains $95 \%$ of the statistical scatter.

Data representing the major production and trade enterprises located in European Union countries and their activity in the implementation of innovations is examined in the empirical research. Using multiple regression and correlation analyses new theoretical assumptions are confirmed.

It was found that the increase of investments into research and development in the European Union of up to 3\% of gross domestic product would significantly improve the activeness of production and trade enterprises.

It was found that there is a stochastic relationship between expansion of information technology, research and development activities in certain countries, and the activeness of production and trade enterprises in the innovation implementation area. It was found that the greatest impact on the activeness of examined companies has the expansion of research and development activity. At the same time it should be noted that the expansion of information technology, research and development activities in specific countries encourages enterprises to implement innovations, and thus the capacity necessary for the development of production and trade. 


\section{Conclusions}

Company practices should be understood and analyzed when examining the application of innovations and prospects of increasing the competitiveness of EU business prospects. Meanwhile, scientific articles pay very little attention to these studies. Literature suggests that the greatest role in innovation implementation is played by major international companies. Their work is exceptionally significant in implementation of innovations. However, there are not many large enterprises among the European Union production and trade companies. Therefore, there is a lack of attention to innovations in small production and trade companies which employ up to nine people. In order to increase competitiveness, these companies should intensify cooperation with large enterprises and, in turn, apply the uptake of innovation strategies.

When examining business practices, it was found that manufacturing companies actively apply technological innovations, and trade companies - product innovations.

When talking about business changes, the implementation of innovations may help enterprises to increase capacity, production or service flexibility, reduce the demand for labor per unit of production, penetrate new markets, increase market share, improve customer service, more efficiently use raw materials and energy, and reduce product costs.

A framework, which consists of twelve criteria, was based on the theoretical results of the study. Herein, such criteria which reflect the implementation of technological innovations, business collaboration, product innovations, process innovations, criterion determining the intensity of competition, the variety of products and services, etc. are included.

The study results show that among the European Union production enterprises, Luxembourg and Slovenia enterprises, and among trade enterprises, Luxembourg enterprises are the most active in the context of adapting to the current environment and implementing innovations.

In this space it becomes clear that companies belonging to member states with smaller markets (Luxembourg, Slovenia, Lithuania) are more active through innovation and adaptation to changing environmental conditions than companies in countries with larger markets (the Czech Republic, Italy, Portugal, Romania).

The results also show that the production and marketing companies are inert: only one fifth of the production and a third of trading companies implement innovations; only a quarter of manufacturing companies and a fifth of trading companies seek to implement them. Therefore it is necessary to clarify corporate activity and innovation-inducing factors.

During the course of research the author has found that a stochastic relationship exists between the expansion of information technology, research and 
development activities in specific countries and the activeness of enterprises in innovation implementation. The greatest influence on examined enterprises has the expansion of research and development activity.

This study has its own limitations. Therefore, further research could extend the presented study to the following directions: first, the diversity of service innovations in the European Union countries could be examined; second, the particularities of innovation implementation in other sectors could be disclosed; third, factors stopping the implementation of innovations could be named; fourth, the implementation of other innovations could be analyzed; also other directions could be specified.

\section{References}

Andriuškevičius, A. (2005), 'Evaluation of Contractors by Using COPRAS - the Multiple Criteria Method', Technological and Economic Development of Economy, 3 (11), 158-169.

Balkyte, A., Valentinavičius, S. (2006), 'Ekonomikos augimo veiksniai ir jų įtaka gyvenimo lygiui Lietuvoje', Verslas, vadyba ir studijos 2005. Mokslo darbai, Vilnius: Technika, 125-136.

Bivainis, J., Drejeris, R. (2009), 'Naujų paslaugų technologijos tinkamumo daugiakriterinis vertinimas', Verslas: teorija ir praktika, 2 (10), 93-106.

Cohen, W.M., Levinthal, D.A. (1998), 'Innovation and Learning: The Two Faces of R\&D — Implications for the Analysis of R\&D Investment'. Economic Journal, 99, 569-596.

Davis, F. (1989), 'Perceived Usefulness, Perceived Ease of Use, and User Acceptance of Information Technology'. MIS Quarterly, 13 (3), 319-339.

Department of Statistics. (2010), Database. Retrieved from http://www.std.lt. 18 Debember 2015.

Deshpande, R., Frederick E., Webster, F.E. (1993), 'Corporate Culture, Customer Orientation, and Innovativeness in Japanese Firms: A Quadrad Analysis'. Journal of Marketing, 57, 23-27.

European Commision. (2011), Retail and Wholesale Trade Sector. Retrieved from http://ec.europa. eu/enterprise/policies/innovation/files/proinno/sector-report-retail_en.pdf. 20 January 2016.

Eurostat. (2010), Innovation statistics. Retrieved from http://epp.eurostat.ec.europa.eu/statistics. 23 February 2016.

Europos Komisija. (2013), European Competitiveness Report: Towards Knowledge Driven Reindustrialisation, Luxembourg: Publications Office of the European Union.

Eurostat. (2006), Science, Technology and Innovation in Europe. Retrieved from http://ec.europa. eu/eurostat. 6 November 2007.

Fang, E. (2008), 'Customer Participation and the Trade-Off Between New Product Innovativeness and Speed to Market'. Journal of Marketing, 72, 90-104.

Ginevičius, R. (2008), 'Normalization of Quantities of Various Dimensions'. Journal of Business Economics and Management, 9 (1), 79-86.

Ginevičius, R., Podvezko, V. (2007), 'Complex Assessment of Sustainable Development of State Regions with Emphasis on Ecological and Dwelling Conditions'. Ekologija, 53, 41-48.

Ginevičius, R., Podvezko, V. (2009), 'Evaluating the Changes in Economic and Social Development of Lithuania Country by Multiple Criteria Methods'. Technological and Economic Development of Economy, 15 (3), 418-436.

Hart, O.A., Barinedum, M.N., Benjamin J.I. (2010), 'The Uptake of Electronic Commerce by SMEs: A Meta Theoretical Framework Expanding the Determining Constructs of TAM and TOE Frameworks'. Journal of Global Business and Technology, 6 (1), 1-27.

Hertog, P. (2000), 'Knowledge Intensive Business Services as Co-producers of Innovation'. International Journal of Innovation Management, 4, 491-528.

Ekonomia - Wroclaw Economic Review 22/1 (2016)

(C) for this edition by CNS 
Hult, G.T., Hurley, R.F., Knight, G.A. (2004), 'Innovativeness: Its Antecedents and Impact on Business Performance'. Industrial Marketing Management, 33, 429-438.

Hurley, R.F., Hult, G.T., Knight, G.A. (2005), 'Innovativeness and Capacity to Innovate in a Complexity of Firm-level Relationships: A Response to Woodside'. Industrial Marketing Management, 34, 281-283.

Jakštas, V. (2001), Pramonès įmonès technologinès plètros projektavimas, Vilnius: Technika.

Jakutis, A., Petraškevičius, V., Stepanovas, A., Šečkutė, L., Zaicev, S. (2005), Ekonomikos teorija, Vilnius: Eugrinmas.

Kaklauskas, A., Gulbinas, A., Krutinis, M., Naimavičienė, J., Šatkauskas, G. (2007), 'Mokymo procese naudojamų pasirenkamų modulių daugiavariantės analizès metodai'. Ūkio technologinis ir ekonominis vystymas, 3 (13), 253-258.

Kildienè, S., Kaklauskas, A., Zavadskas, E.K. (2011), 'COPRAS Based Comparative Analysis of the European Country Management Capabilities within the Construction Sector in the Time of Crisis'. Journal of Business Economics and Management, 12 (2), 417-434.

Knašas, A.B. (2002), Inovacijos strategijos rinku internacionalizavimo salygomis, Vilnius: Technika. Koellinger, Ph.D., Thurik, A.R. (2009), 'Entrepreneurship and the Business Cycle'. Tinbergen Institute Discussion Paper, No. 09-032/3, Retrieved from http://hdl.handle.net/10419/86678Re. 18 November 2015.

Lee, Y., Shin, J., Park, Y. (2012), 'The Changing Pattern of SME’s Innovativeness through Business Model Globalization'. Technological Forecasting \& Social Change, 79, 832-842.

Maceika, A. (2003), Technologiju perdavimo vadyba, Vilnius: Technika.

Marelli, E., Signorelli, M. (2010), 'Employment, Productivity and Models of Growth in the EU'. International Journal of Manpower, 31 (7), 732-754.

Malinauskas, P., Kalibatas, D. (2005), 'Racionalių statybos technologiniu procesų parinkimas taikant COPRAS metodą'. Ükio technologinis ir ekonominis vystymas, 11 (3), 197-203.

Melnikas, B. (2002), Transformacijos, Vilnius: Vaga.

Melnikas, B., Chlivickas, E., Jakubavičius, A., Lobanova, L., Pipirienė, V., Burinskienė, A. (2008), Tarptautinis verslas, Vilnius: Technika.

Mets, T. (2012), Creative Business Model Innovation for Globalizing SMEs Entrepreneurship Creativity and Innovative Business Models. Retrieved from http://www.intechopen.com/ books/entrepreneurship-creativity-and-innovative-businessmodels/creative-business-model-innovation-for-globalizing-smes. 14 March 2016.

Podvezko, V. (2005), 'Ekspertų įverčių suderinamumas'. Ūkio technologinis ir ekonominis vystymas, 2 (11), 101-107.

Porter, M. (1999), The Competitive Advantage of Nations, New York: Free Press.

Rogers, E.M. (1962), Diffusion of Innovations, Glencoe: Free Press.

Olson, E.M., Slater, S.F., Hult, G.T. (2005), 'The Performance Implications of Fit Amount Business Strategy, Marketing Organization Structure, and Strategic Behavior'. Journal of Marketing, 69, $49-65$.

Tajeddini, K. (2010), Effect of Customer Orientation and Entrepreneurial Orientation on Innovativeness: Evidence from the Hotel Industry in Switzerland. Retrieved from www.elsevier.com/ locate/tourman. 25 February 2016.

Tornatzky, L., Fleischer, M. (1990), The Process of Technology Innovation, Lexington: MA, Lexington Books.

Turskis, Z., Zavadskas, E.K., Peldschus, F. (2009), 'Multi-criteria Optimization System for Decision Making in Construction Design and Management'. Engineering Economics, 1 (61), 7-17. 
Woodside, A.G. (2005), 'Firm Orientations, Innovativeness, and Business Performance: Advancing a System Dynamics View Following a Comment on Hult, Hurley, and Knight's 2004 Study'. Industrial Marketing Management, 34, 275-279.

Zavadskas, E.K., Simanauskas, L., Kaklauskas, A. (1999), Sprendimu paramos sistemos statyboje, Vilnius: Technika. 


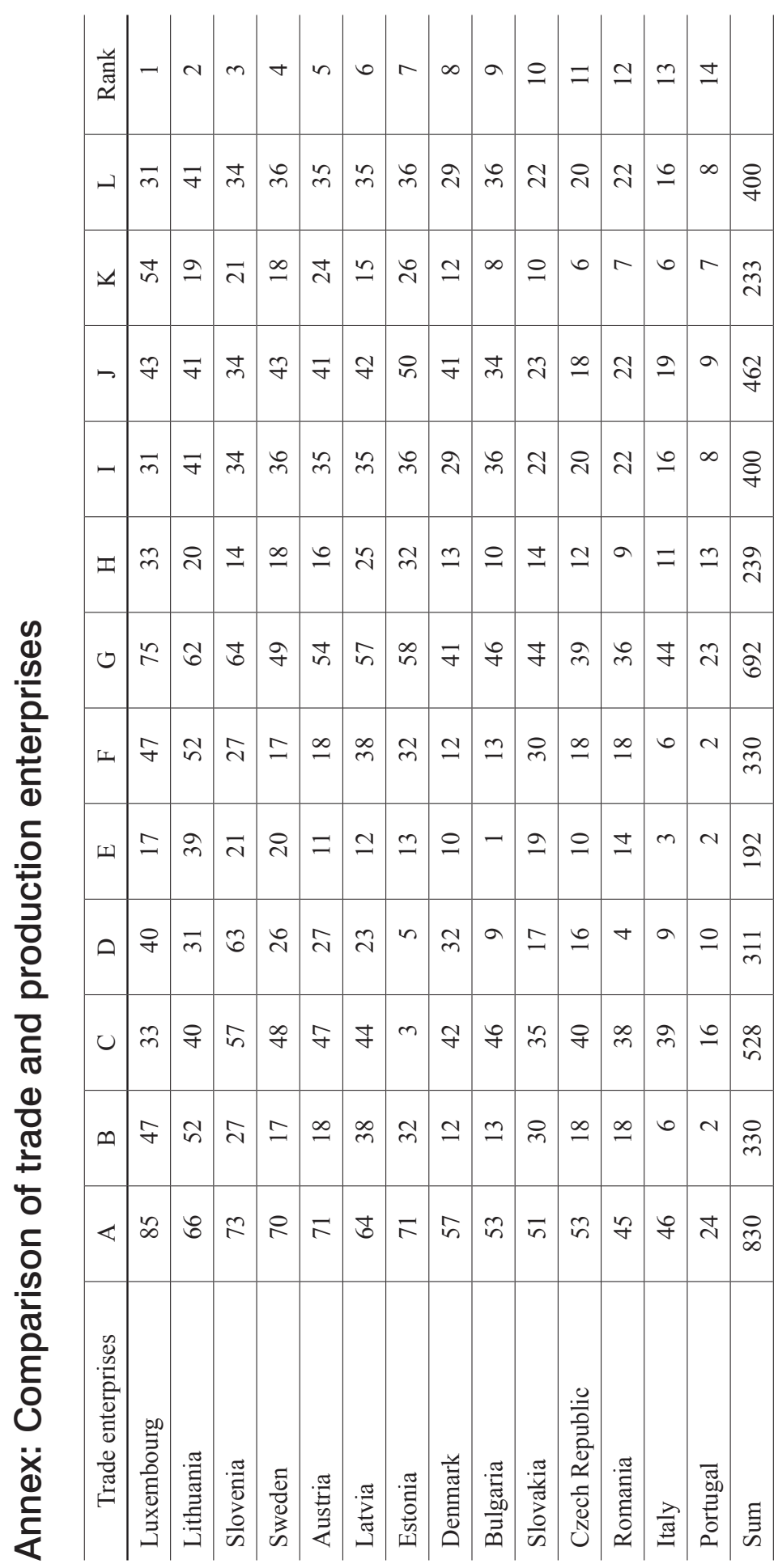

Ekonomia - Wroclaw Economic Review 22/1 (2016)

(C) for this edition by CNS 


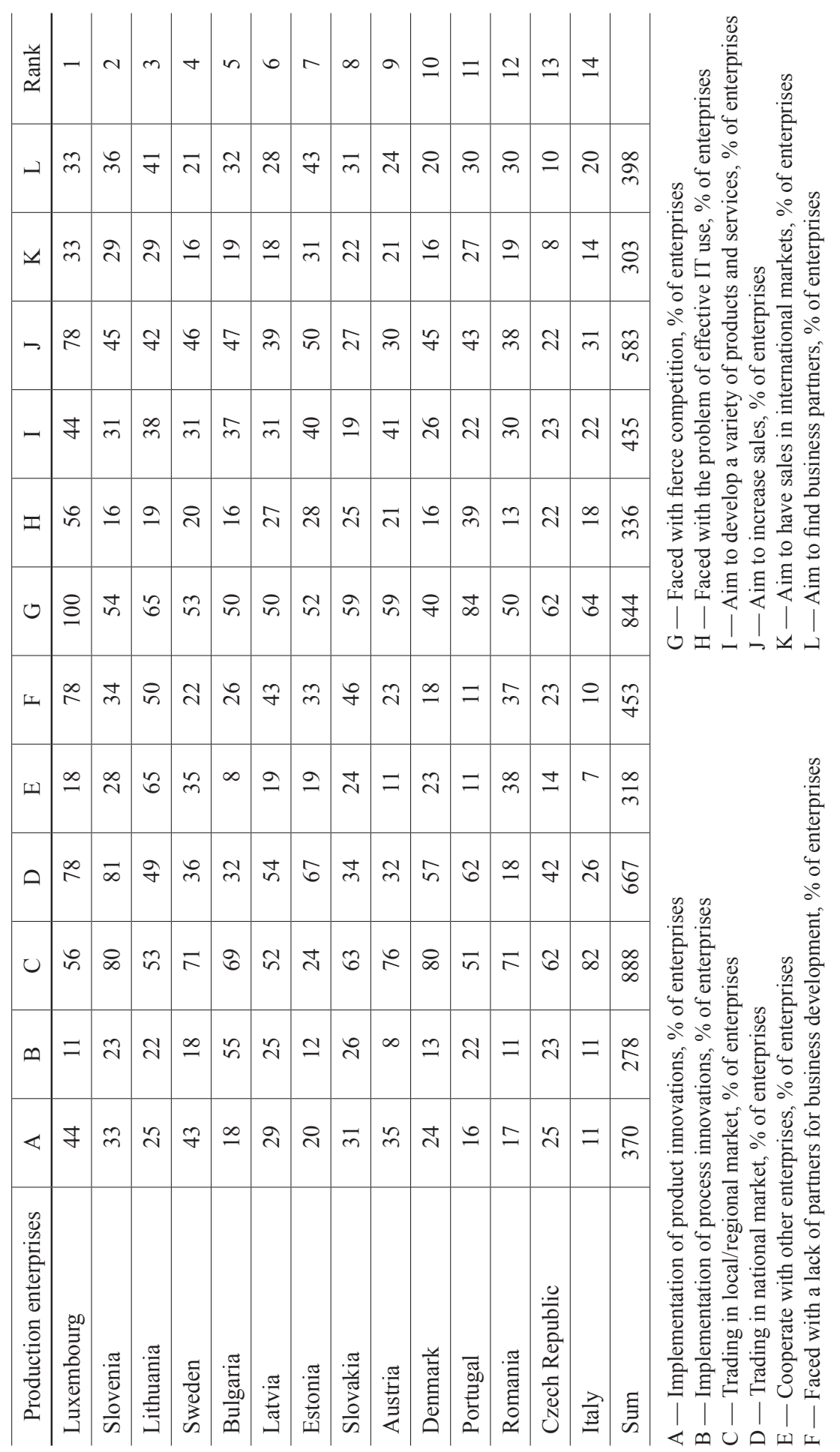

